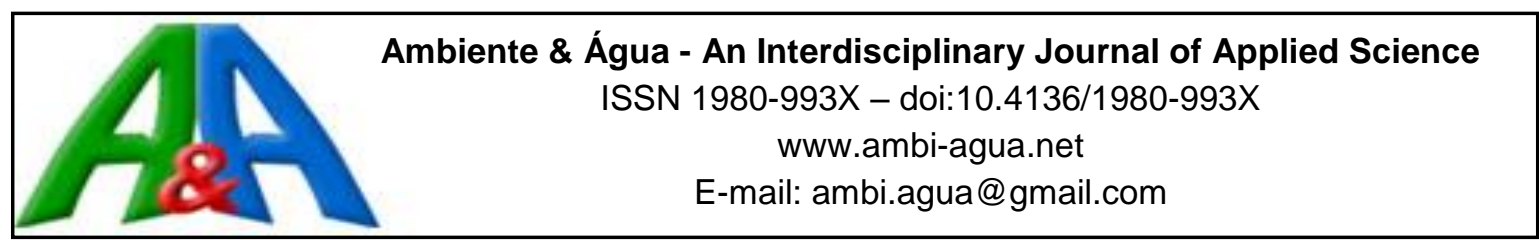

\title{
Determination of carbamazepine and diazepam by SPE-HPLC-DAD in Belém River water, Curitiba-PR/Brazil
}

ARTICLES doi:10.4136/ambi-agua.2196

Received: 05 Oct. 2017; Accepted: 05 Jan. 2018

\author{
Beatriz Böger ${ }^{*}$; Bianca do Amaral $^{2}$; Priscila Lagner da Silveira Estevão \\ Ricardo Wagner'1; Patricio Guillermo Peralta-Zamora² ${ }^{2}$ Eliane Carneiro Gomes ${ }^{1}$ \\ ${ }^{1}$ Universidade Federal do Paraná (UFPR), Curitiba, PR, Brasil \\ Programa de Pós-Graduação em Ciências Farmacêuticas (PPGCF). E-mail: beatrizboger@gmail.com, \\ sorw2003@yahoo.com.br, ecarneirogomes@gmail.com \\ ${ }^{2}$ Universidade Federal do Paraná (UFPR), Curitiba, PR, Brasil \\ Programa de Pós-Graduação em Química (PPGQ).E-mail: biancadoamaral_@ hotmail.com, \\ priscilalagner@hotmail.com, zamora@ufpr.br \\ *Corresponding author
}

\begin{abstract}
This work sought to determine the two psychotropic drugs most commonly released by Psychosocial Care Centers (CAPS) into urban river waters (Belém sub-basin, Curitiba, PR, Brazil). A simple analytical method using SPE followed by a HPLC-DAD was developed and validated. Strata-X® cartridges were used to extract (carbamazepine) $C Z$ and diazepam (DZ) from water and SPE conditions were optimized by $2^{3}$ factorial design. The validated method was specific for target compounds; correlation coefficients were above 0.9998, recovery between 85.8 and $98.4 \%$ and precision below $6.60 \%(\mathrm{RSD}, \mathrm{n}=3)$. This method was successfully applied to analyze river samples and pollution hotspots were identified. The $\mathrm{CZ}$ and DZ concentrations found ranged from 0.670 to $0.856 \mu \mathrm{g} \mathrm{L}^{-1}$ and from LOQ to $0.763 \mu \mathrm{g} \mathrm{L}^{-1}$, respectively, and confirmed that drug consumption is directly related to river pollution in the studied region.
\end{abstract}

Keywords: carbamazepine, diazepam, emerging pollutants.

\section{Determinação de carbamazepina e diazepam por SPE-HPLC-DAD nas águas do rio Belém em Curitiba-PR/ Brasil}

\section{RESUMO}

Este trabalho teve como objetivo determinar duas drogas psicotrópicas mais dispensadas pelos Centros de Atenção Psicossocial (CAPS) nas águas de um rio urbano (sub-bacia do rio Belém, Curitiba - PR, Brasil). Foi desenvolvido e validado um método analítico SPE seguido de HPLC-DAD. Os cartuchos Strata-X® foram utilizados para extrair carbamezepina (CZ) e diazepam (DZ) das águas e as condições de SPE foram otimizadas por um planejamento fatorial $2^{3}$. O método validado foi específico para compostos alvo. Os coeficientes de correlação foram superiores a 0,9998, a recuperação entre 85,8 e 98,4\% e a precisão abaixo de 6,60\% (RSD, $\mathrm{n}=3$ ). Este método foi aplicado com sucesso para analisar amostras de rios e pontos críticos de poluição foram reconhecidos. A CZ e DZ foram encontradas em concentrações variando de 
0,670 a $0,856 \mu \mathrm{g} \mathrm{L}{ }^{-1}$ e de LOQ a $0,763 \mu \mathrm{g} \mathrm{L}{ }^{-1}$, respectivamente, confirmam que o consumo de drogas está diretamente relacionado à poluição do rio na região estudada.

Palavras-chave: carbamazepina, diazepam, poluentes emergentes.

\section{INTRODUCTION}

About 450 billion people worldwide have some mental or behavioral disorder, and this number is expected to grow significantly up until 2020 (Menken et al., 2000). Psychiatric drugs are of particular concern because of their toxicity, persistence and the increased consumption in the last decade (Stuart et al., 2012; Subedi and Kannan, 2015; FENAFAR, 2015). Diazepam (DZ) is a psychotropic medication of the benzodiazepine class that are selective central nervous system modifiers and can be classified as anxiolytic. They are the most commonly used in the world (Sebastiaão and Pelá, 2004). About 1-3\% of the Western population has already consumed diazepam regularly for over a year and in Brazil about $10 \%$ of adults have been prescribed these drugs (Huf et al., 2000; CREMESP, 2002). Carbamazepine (CZ) is a controlled drug in Brazil and is considered a mood stabilizer (Rang et al., 2003). In 2008, carbamazepine, with anticonvulsant action, was among the five active ingredients most consumed in Brazil (Mota, 2011). Carbamazepine has been detected in the surface of drinking water in more than 29 countries (Ebert et al., 2014). Diazepam was found in 8 of 20 wastewater treatment plants at relatively low concentrations $\left(<0.04 \mathrm{mg} \mathrm{L}^{-1}\right)$ with a high frequency of detection in these treatment plants (Cabeza, 2012).

Although the present knowledge in the occurrence and behavior of these compounds in rivers is well documented in the world ( $\mathrm{Li}, 2014$; Pal et al., 2013; Patrolecco et al., 2013; Camacho-Muñoz et al., 2009; Madureira et al., 2010), in Brazil it is still very limited (Montagner and Jardim, 2011; Campanha et al., 2015; Almeida et al., 2013). Only eight quantification studies of emerging pollutants of pharmaceutical origin were performed between 2000-2015 in Brazil. Among these studies, only three psychoactive drugs were investigated in aqueous matrices. Also, the southern region has only one study on hospital sewage and none on rivers (Böger et al., 2015).

Pharmaceuticals are released into the environment through excretions via feces and urine in a conjugated or unmetabolized way, and through disposal of outdated medicines in household sewage and effluents of wastewater treatment plants (WWTPs) (Subedi and Kannan, 2015; Alygizakis et al., 2016). While the toxic effects related to the disposition of these compounds are not fully known, recent studies demonstrate some interference in the metabolism and behavior of aquatic organisms (Fent et al., 2006; Morley, 2009), crossing all biological hierarchy, from cells and organs, and even ecosystems (Jorgensen and Halling-Sorensen, 2000). A recent study showed that exposure of fish and benthic invertebrates to psychoactive drugs altered their behavioral responses (Brodin et al., 2014; Rosi-Marshall et al., 2015).

Due to the matrix complexity and the low concentration of the target analytes, the direct analysis of these drugs is not feasible. Also, sample pretreatment is necessary to eliminate the interferences and to achieve desirable limits of detection and quantification. Solid phase extraction (SPE) has been applied to trace analysis to obtain significant preconcentration factors, with the use of smaller volumes of solvent (Madureira et al., 2010; Huntscha et al., 2012; Amaral et al., 2014).

Recently, the emerging organic pollutants have been investigated worldwide; nevertheless, there is no legislation that considers pharmaceuticals as micropollutants. The analytical techniques for medicine quantification and identification are well-established in governmental agencies such ANVISA in Brazil. Despite this, conventional methodologies are used for raw material and commercial product quality (Anvisa, 2003). Hence, the development of rapid, 
cheap, sensitive and accurate methods for monitoring pharmaceuticals at trace level have represented an analytical challenge in the last years. Further, the simultaneous determination of compounds with different chemical nature, from various therapeutic classes (Gros et al., 2006; Gomez et al., 2007) and also track pharmaceuticals in highly polluted aquatic environments, decreased time, and reduced overall cost is still a challenge. Most of these new methodologies are based on liquid chromatography-tandem mass spectrometry (LC-MS/MS) due to its high sensitivity and ability to confirm the compound's identity; however, the application of this sophisticated and expensive technology is not yet available in all laboratories. Taking into account the previously mentioned concerns, the purpose of this work was to develop an analytical method based on a single and efficient preconcentration procedure based on solidphase extraction (SPE) followed by high-performance liquid chromatography with diode array detection (HPLC-DAD) analysis, demonstrating that this methodology is very useful for detecting levels of carbamazepine and diazepam in polluted water samples. These analytes were chosen based on survey of the most prescribed drug by Psychosocial Care Center (CAPS) in Curitiba, Paraná- BR performed in this work.

\section{MATERIALS AND METHODS}

\subsection{Chemicals and materials}

Carbamazepine (CZ, 5H-Dibenz $[b, f]$ azepine-5-carboxamide) and Diazepam (DZ, 7-Chloro-1-methyl-5-phenyl-3H-1,4-benzodiazepin-2(1H)-one) were purchased from USP (Rockville, MD, USA).

All the other solvents used were HPLC grade and supplied by J. T. Baker (Philipsburg, NJ, USA). Ultrapure water was obtained using Milli-Q system coupled with a UV lamp (18.2 $\mathrm{M} \Omega \mathrm{cm}$, Bedford, MA, USA). 0.45- $\mu \mathrm{m}$ glass fiber filters were purchased from Millipore (Macherey Nagel). Stock solutions for individual standards $\left(1000 \mathrm{mg} \mathrm{L}^{-1}\right)$ were prepared in methanol and stored in the dark at $-6^{\circ} \mathrm{C}$. Stock solutions were stable, and no evidence of degradation of the analytes was observed on the chromatograms during the six-month study period. Working solutions were prepared daily by diluting the stock solution with a suitable solvent. The $\mathrm{pH}$ of the solutions was measured by OHAUS Starter $2100 \mathrm{pH}$-meter.

\subsection{Sample collection}

The river studied was chosen according to the geographical location of the CAPS evaluated. These two CAPS are located on the watershed of Belém. Therefore, the river selected for the study was the sub-basin of Belém River (tributary of the Iguaçu River, which is one of the basins used for water supply in other cities in Paraná), considered a contaminated hotspot. Several samples were collected at three distinct areas of the Belém River: two considered highly polluted since most waste generated in this region is not suitably treated and is directly discharged into the Belém River (the mouth and about $7 \mathrm{~km}$ from the headspring of the river) and the other with low levels of pollution as it was near the headspring. The samples were fortified with $2.56 \mu \mathrm{g} \mathrm{L}^{-1}$ of $\mathrm{DZ}$ and $2.26 \mu \mathrm{g} \mathrm{L} \mathrm{L}^{-1}$ of $\mathrm{CZ}$ to monitor retention time $\left(\mathrm{T}_{\mathrm{R}}\right)$ of drug. The water samples were collected during May, June, July and October. Two liters of river water samples were collected into $2.5 \mathrm{~L}$ pre-rinsed amber glass bottles. Upon collection, all samples were immediately transported at $4^{\circ} \mathrm{C}$ to the laboratory and vacuum-filtered through a $0.45-\mu \mathrm{m}$ glass fiber filter with a $47 \mathrm{~mm}$ diameter (Millipore). The $\mathrm{pH}$ of filtered samples was adjustedd to 4.00. Each sample was divided into different volumetric flasks, then stored in darkness at $4^{\circ} \mathrm{C}$ and extracted within a maximum of $24 \mathrm{~h}$ after collection. 


\subsection{Solid-phase extraction}

SPE was performed on a PrepSep 20-port vacuum manifold (Waters, Milford, MA, USA) with Strata- $X^{\circledR}$ cartridges (Phenomenex, $200 \mathrm{mg} / 3 \mathrm{~mL}$ ). The SPE operational variables such as conditioning and elution solvent, analytes concentration and sample volume, were optimized by a two-level factorial design $\left(2^{3}\right.$ with triplicate of center point) according to Table 1 . The assays were carried out in a randomized mode. The response evaluated was the recovery of psychoactive drugs.

In the optimized SPE procedure, cartridges were conditioned with two aliquots of acetonitrile $(2.50 \mathrm{~mL})$ and two aliquots of ultrapure water $\mathrm{pH} 4(2.50 \mathrm{~mL})$ before each run. Sequentially, water samples at $4.00 \mathrm{pH}$ were percolated through the cartridges at a constant flow rate of $3 \mathrm{~mL} \mathrm{~min}^{-1}$. Afterward, elution was performed with $5.00 \mathrm{~mL}$ of acetonitrile. The extracts were evaporated to dryness in a thermostatic bath at $30^{\circ} \mathrm{C}$ under a gentle nitrogen stream. The residues were dissolved in $1.00 \mathrm{~mL}$ of water, and $15 \mu \mathrm{L}$ was injected into the HPLC system. The $\mathrm{pH}$ and reconstitution volume were evaluated separately.

Table 1. Factors and levels analyzed in two-level full factorial design.

\begin{tabular}{lccc}
\hline \multirow{2}{*}{ Factor } & \multicolumn{3}{c}{ Level } \\
\cline { 2 - 4 } & -1 & 0 & +1 \\
\hline \multirow{2}{*}{ Concentration } & $1.28 \mu \mathrm{g} \mathrm{L}^{-1} \mathrm{DZ}$ & $2.56 \mu \mathrm{g} \mathrm{L}^{-1} \mathrm{DZ}$ & $3.84 \mu \mathrm{g} \mathrm{L}^{-1} \mathrm{DZ}$ \\
Sample volume & $1.13 \mu \mathrm{g} \mathrm{L}^{-1} \mathrm{CZ}$ & $2.26 \mu \mathrm{g} \mathrm{L}^{-1} \mathrm{CZ}$ & $3.39 \mu \mathrm{g} \mathrm{L}^{-1} \mathrm{CZ}$ \\
Conditioning/elution solvent & $100 \mathrm{~mL}$ & $200 \mathrm{~mL}$ & $300 \mathrm{~mL}$ \\
\hline
\end{tabular}

\subsection{HPLC-DAD analysis}

Chromatographic analyses were performed with the Agilent 1260 Infinity Quaternary LC system (Agilent Technologies, Waldbronn, Germany) equipped with an autosampler, quaternary gradient pump, and diode array detector (DAD) system. Separation was achieved in a $100 \mathrm{~mm} \times 2.1 \mathrm{~mm}, 5 \mu \mathrm{m}$ particle size Waters XBridge BEH C18 column. The data were collected with OpenLab EZChrom Elite software. The chromatographic conditions were optimized based on previous information in literature (INMETRO, 2010; Madureira et al., 2010). Hence, an isocratic elution mode was selected for simultaneous determination of carbamazepine and diazepam with methanol and ultrapure water $(60: 40 \mathrm{v} / \mathrm{v})$ as mobile phase at a flow rate of $0.4 \mathrm{~mL} \mathrm{~min}^{-1}$. Separations were performed at a $30^{\circ} \mathrm{C}$. The following wavelengths were monitored: $254 \mathrm{~nm}$ (DZ) and $286 \mathrm{~nm}(\mathrm{CZ})$, which allowed a selective analysis with a suitable absorption of the studied compounds. The optimized chromatographic condition had 8.0 minutes of total run time.

\subsection{Method validation}

The method validation for the determination of pharmaceuticals in river water was performed with the following parameters: linearity, detection and quantification limits, precision and accuracy ( $\mathrm{n}=3$ for all assays) according to guidelines described by the National Agency of Health Surveillance (Agência Nacional de Vigilância Sanitária - ANVISA) (Anvisa, 2003). All procedures were performed with preconcentration step.

\section{RESULTS AND DISCUSSION}

\subsection{Psychotropic drugs studied}

This study aims to analyze the most commonly used psychotropic drugs in the Psychosocial Network, the Psychosocial Care Center (CAPS) in Curitiba, Paraná, BR, assisted 
by Unified Health System (SUS), which consists of healthcare venuess for people suffering from mental disorders and needs arising from the use of crack, alcohol, and other drugs.

A transverse quantitative analysis was performed to search for information in the Specific Registration Books of controlled drugs in CAPS for the years 2011 to 2014. There were 10,897 drugs dispensed for emergency use in mental disorders. The Brazilian Common Denomination (DCB), pharmaceutical forms and concentrations that are exempted from the following drug classes was considered: antidepressants, anxiolytics, antiepileptics, antipsychotics, anticholinergics, and hypnotic/sedative. Based on this survey, carbamazepine and diazepam were among the most prescribed antipsychotics (Diazepam $5 \mathrm{mg}$ pill (11.86\%) and Carbamazepine $200 \mathrm{mg}$ (9.08\%)). Hence, the both psychotropic drugs were selected for further investigation.

\subsection{Solid phase extraction}

Pre-concentration methods are essential to environmental analysis since the target analytes are at low concentrations (the trace levels $-\mu \mathrm{g} \mathrm{L}^{-1}$ ) (Amaral et al., 2014). Initially, the selection of $\mathrm{pH}$ included different values of 4.00, 6.50 and $8.00(\mathrm{n}=3)$. Water acidified to $\mathrm{pH} 4.00$ showed better recovery results to both analytes because $\mathrm{CZ}$ ensures the prevalence of the neutral form of compounds in the solution (around pka) and DZ is undissociated; however the best recoveries were obtained in acidic media compared with neutral and basic $\mathrm{pH}$ recoveries.

To determine the influence of conditioning and elution solvent, analytes concentration and sample volume on the preconcentration system, a two-level full factorial design, $2^{3}$ with 8 runs was employed. Based on central point standard deviation (CZ: 0.38; DZ: 0.15), 3-way interactions were statistically significant (95\% of confidence level) for both analytes. Hence, the factors can not be evaluated individually. As shown in Figure 1, this higher-order effect means there are several conditions which provide proper psychoactive drug recovery.

The optimized SPE conditions were in the low level for all variables $(5.00 \mathrm{~mL}$ of ACN followed by $5.00 \mathrm{~mL}$ of ultrapure water $\mathrm{pH} 4.00$ as conditioning solvents, $5.00 \mathrm{~mL}$ of ACN as an elution solvent, $100 \mathrm{~mL}$ of sample volume and $1.13 \mu \mathrm{g} \mathrm{L}^{-1}$ to $\mathrm{CZ}$ and $1.28 \mu \mathrm{g} \mathrm{L}^{-1}$ to DZ) and were employed in further experiments. Similar recoveries were estimated by Patrolecco et al. (2013) employing Strata X cartridge (80 to 93\% to CZ) and by Madureira et al. (2010) using Oasis HLB cartridges ( 81 to $91 \%$ to CZ and 86 to $91 \%$ to DZ).

Reconstitution volume was also investigated. Recoveries of around $80 \%$ with RSD below $3.7 \%$ were obtained for $\mathrm{CZ}$ and $\mathrm{DZ}$ at $1.00 \mathrm{~mL}$ of ultrapure water. Meanwhile, volumes of 0.500 and $0.250 \mathrm{~mL}$ recovered less than $70 \%$ of both analytes. Moreover, an enrichment factor of 100 times was achieved.
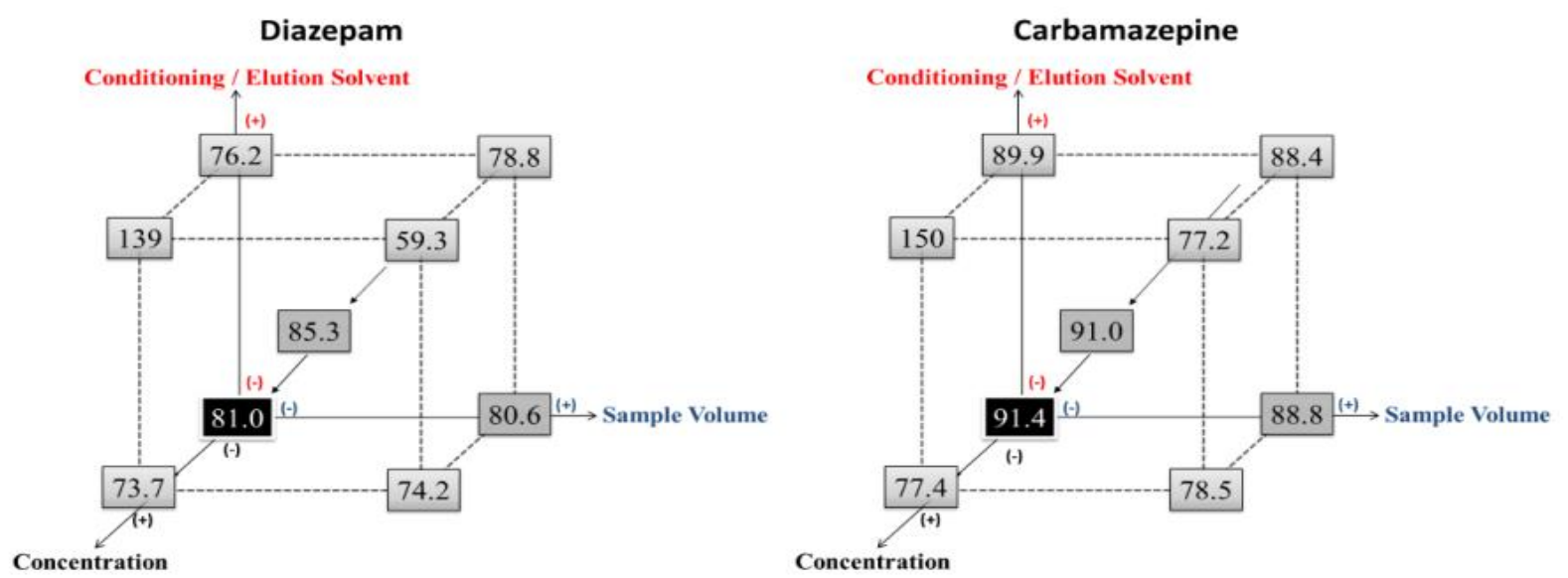

Figure 1. Graphical representation of SPE optimization by $2^{3}$ factorial design. Recovery observed in each assay appears in the boxes. 


\subsection{Method validation}

Figure 2 shows the chromatograms obtained for the proposed method. Well-resolved peaks were observed, for which the retention times were 1.47 minutes and 3.07 minutes for $\mathrm{CZ}$ and DZ, respectively.

The linearity of the method was studied in ten different concentrations of analyte in triplicate in the range between 10.0 e $1500 \mu \mathrm{g} \mathrm{L}^{-1}$. The proposed method showed good linear range between $20-1500 \mu \mathrm{g} \mathrm{L}^{-1}$ to $\mathrm{CZ}$ and $40-1500 \mu \mathrm{g} \mathrm{L}^{-1}$ to DZ, with excellent coefficients of determination $(\mathrm{R}>0.999)$ for both analytes, as recommended by ANVISA (2003). Angular coefficients were used to evaluate method sensitivity, which showed slightly more sensitivity to carbamazepine (Figure 2C).

Selectivity was observed by the association of the $T_{R}$ and DAD spectra, standards in a pure solvent and standards in matrix ensures that the signal measured is not influenced by matrix interferences. This observation guarantees that the method is selective for the pharmaceuticals and can be used for monitoring purposes in river water samples. The RSD values were obtained as a result of a precision estimation of the $t_{\mathrm{R}}$ between the standard in solvent solutions, and spiked matrix were below $2.45 \%(n=18)$. The difference in the baseline shift observed at the beginning of chromatograms is entirely related to the absorption of humic substances commonly present in river water samples, which due to its high conjugated system caused this characteristic band (Moffat et al. 2004). However, in our study, this fact did not interfere with the determination of the studied compounds.

The instrumental precision was estimated by repeatability and intermediate precision assays and was expressed as percent relative standard deviation (\%RSD) of replicate measurements using the peak areas for calculation. Table 2 summarizes the precision results from replicate measurements at three different concentration levels $\left(50.0 \mu \mathrm{g} \mathrm{L}^{-1}, 500 \mu \mathrm{g} \mathrm{L}^{-1}\right.$, and $1000 \mu \mathrm{g} \mathrm{L}^{-1}, \mathrm{n}=3$ ) for each studied psychoactive compound.

Repeatability of replicate measurements was satisfactory, with RSD values below $6.06 \%$ and $3.64 \%$ for $\mathrm{CZ}$ and DZ, respectively. The intermediate precision showed RSD values below $3.87 \%$ for $\mathrm{CZ}$ and $6.61 \%$ for DZ (Table 2). The Instituto Nacional de Metrologia, Normalização e Qualidade Industrial (INMETRO, 2010) determines a maximum RSD value of up to $20 \%$. ANVISA (2003) recommends that the coefficients of variation should not exceed $5 \%$ for the determination of drugs in medicine and more complex matrices, such as serum, blood or plasma, but accepts a value of up to $15 \%$. Hence, the method's precision was satisfactory within the maximum value permitted by applicable Brazilian legislation.

Table 2. Repeatability, intermediate precision RSD (\%) and recovery values (\%) at three different concentration levels.

\begin{tabular}{|c|c|c|c|c|c|c|}
\hline & \multicolumn{6}{|c|}{ Concentration levels $\left(\mu g L^{-1}\right)$} \\
\hline & \multicolumn{2}{|c|}{$50.0(n=3)$} & \multicolumn{2}{|c|}{$500(n=3)$} & \multicolumn{2}{|c|}{$1000(n=3)$} \\
\hline & $\mathrm{CZ}$ & DZ & $\mathrm{CZ}$ & DZ & $\mathbf{C Z}$ & DZ \\
\hline Repeatability (\%) & 6.06 & 1.34 & 0.640 & 3.64 & 0.420 & 2.15 \\
\hline Intermediate precision $(\%)$ & 3.87 & 6.61 & 0.820 & 0.240 & 1.56 & 0.210 \\
\hline Recovery \pm RSD $(\%)$ & $98.3 \pm 4.46$ & $98.4 \pm 5.32$ & $89.7 \pm 2.25$ & $92.7 \pm 10.7$ & $85.8 \pm 3.86$ & $89.7 \pm 9.07$ \\
\hline
\end{tabular}

Accuracy was established based on $\mathrm{CZ}$ and DZ recovery, which was performed by extracting and analyzing triplicate ultrapure water samples spiked with analytes $\left(50.0 \mu \mathrm{g} \mathrm{L}^{-1}\right.$, $500 \mu \mathrm{g} \mathrm{L}^{-1}$ and $1000 \mu \mathrm{g} \mathrm{L}^{-1}$ ). The results of recovery experiments are reported in Table 2, which shows that the method is accurate within the desired recovery range. Similar recoveries were found in real samples (Patrolecco et al., 2013, Madureira et al., 2010) 

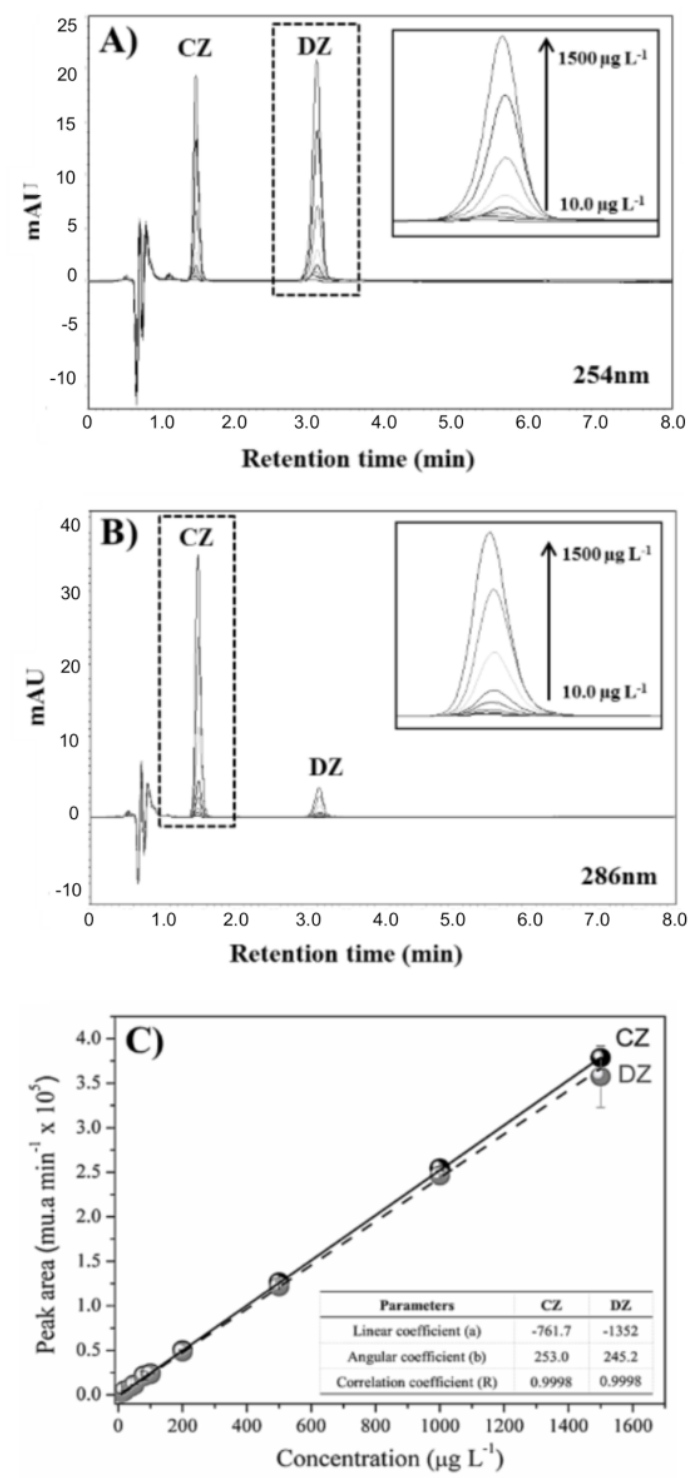

Figure 2. HPLC-DAD chromatograms of a standard mixture of the psychoactive at 10 to $1500 \mu \mathrm{g} \mathrm{L}^{-1}$ performed under the optimized conditions: A) DZ and B) CZ. C) Analytical curves for $\mathrm{CZ}$ at $286 \mathrm{~nm}$ and DZ at $254 \mathrm{~nm}$.

Limits of detection and quantification of the developed method were estimated by the relation of the intercept standard deviation $(s)$ and the value of the calibration curve slope $(\mathrm{S})$, according to Equations 1 and 2:

$L O D=\frac{3,3_{S}}{S}$

$L O Q=\frac{10_{s}}{S}$

The LODs and LOQs were $0.0670 \mu \mathrm{g} \mathrm{L}^{-1}$ and $0.209 \mu \mathrm{g} \mathrm{L}^{-1}$ to $\mathrm{CZ}$ and $0.130 \mu \mathrm{g} \mathrm{L}^{-1}$ and $0.435 \mu \mathrm{g} \mathrm{L}^{-1}$ to DZ. These results were close to those described in the literature (Madureira et al. 2010; Ebert et al. 2014).

\section{IPABH}

Rev. Ambient. Água vol. 13 n. 2, e2196 - Taubaté 2018 
The LOD and LOQ obtained in this work were lower than Madureira et al. (2010) have found with the SPE method (LOD and LOQ to CZ of 3.8 and $15 \mu \mathrm{g} \mathrm{L}^{-1}$, respectively, and to DZ 10.3 and $40 \mu \mathrm{g} \mathrm{L}^{-1}$, respectively). Ebert et al. (2014) related that the global mean concentration in surface water to $\mathrm{CZ}$ is between 0.187 and $8.05 \mu \mathrm{g} \mathrm{L}^{-1}$. Based on that, the proposed method would be able to detect $\mathrm{CZ}$ in concentrations lower than this minimum limit.

The evaluation of robustness was made by analyses of the influence of variations in column temperature at $20^{\circ} \mathrm{C}, 25^{\circ} \mathrm{C}$ and $30^{\circ} \mathrm{C}$, respectively, and in flow rates of $0.3,0.4$ and $0.5 \mathrm{~mL} \mathrm{~min}{ }^{-1}$. This data allowed us to correlate each area of peak to the corresponding chromatographic retention time. For robustness evaluation, small changes in flow rate $( \pm 10 \%)$ and column temperature $\left( \pm 5^{\circ} \mathrm{C}\right)$ did not make significant changes to resolution or recovery.

\subsection{Psychoactive pharmaceuticals in the Belém River water}

To demonstrate the applicability of the developed method, three sampling locations in the Belém River were selected according to the level of pollution in each area (low, medium and high pollution). Water samples were collected in May, June, July and October 2015 (Table 3).

The mouth of the river is the most-polluted site. It is fully inserted in the city of Curitiba; there are many irregular houses on its margins. Many of these houses are not connected to the city's sewage network, thus discarding their sewage into the river.

Table 3. The average concentration of residues found in different locations in the river in each collection.

\begin{tabular}{|c|c|c|c|c|c|}
\hline \multirow{2}{*}{ Locations } & \multirow{2}{*}{ Analytes } & \multicolumn{4}{|c|}{ Average concentration $\left(\mu \mathrm{g} \mathrm{L}^{-1}\right)$} \\
\hline & & May & June & July & October \\
\hline \multirow{2}{*}{ Headspring } & $\mathrm{CZ}$ & $<\mathrm{LOQs}$ & $<$ LOQs & 0.371 & $\mathrm{nd}^{*}$ \\
\hline & $\mathrm{DZ}$ & $<\mathrm{LOQs}$ & $\mathrm{nd}^{*}$ & nd $^{*}$ & $\mathrm{nd}^{*}$ \\
\hline \multirow{2}{*}{ Middle of river } & $\mathrm{CZ}$ & $<\mathrm{LOQs}$ & $<$ LOQs & $<$ LOQs & $\mathrm{nd}^{*}$ \\
\hline & $\mathrm{DZ}$ & $\mathrm{nd}^{*}$ & nd $^{*}$ & $\mathrm{nd}^{*}$ & $\mathrm{nd}^{*}$ \\
\hline \multirow{2}{*}{ Mouth } & $\mathrm{CZ}$ & $\mathrm{nd}^{*}$ & 0.856 & $<$ LOQs & $\mathrm{nd}^{*}$ \\
\hline & $\mathrm{DZ}$ & $\mathrm{nd}^{*}$ & 0.763 & $\mathrm{nd}^{*}$ & $\mathrm{nd}^{*}$ \\
\hline
\end{tabular}

*nd: not detected.

Carbamazepine was found higher than LOQ in headspring (July-CZ $=0.371 \mu \mathrm{g} \mathrm{L}^{-1}$ ) and the both at the Belém River mouth (June-CZ $\left.=0.856 \mu \mathrm{g} \mathrm{L}^{-1}, \mathrm{DZ}=0.763 \mu \mathrm{g} \mathrm{L}^{-1}\right)$ in the second and third collections, which are consistent with the results that similar work reported (Ebert et al., 2014, Patrolecco et al., 2013). These collections were performed during a dry period (winter), which increases the analytes concentration and lowers degradation rates. Further, during the spring (October), the increase of rain volume and warm weather (INMET, 2015) promotes the dilution of analytes and increases degradation rates. Therefore, $\mathrm{CZ}$ and DZ were not detected at any of the collection points. The highest frequency of CZ detection is indicative of inadequate sewage disposal along the river localized in the region that this drug is widely distributed by CAPS, as early mentioned.

$\mathrm{CZ}$ were found in the Tiber River (Italy) at the concentration level of $0.063 \mu \mathrm{g} \mathrm{L}^{-1}$ (Patrolecco et al., 2013). Madureira et al. (2010) found $\mathrm{CZ}$ at $0.0327 \mu \mathrm{g} \mathrm{L} \mathrm{L}^{-1}$ and did not detect DZ in the Douro River estuary (Portugal). Campanha et al. (2015) found CZ in $71 \%$ of analyzed samples between 0.50 and $0.215 \mu \mathrm{g} \mathrm{L}^{-1}$ in the Monjolinho River, São Carlos, SP. According Clara et al. (2004), CZ could be considered a qualified parameter for detecting wastewater in aquatic environments due to its high persistence.

Carbamazepine and diazepam were found to be ubiquitous (present in 58.3\% of samples collected) and persistent in river water. Here again, a strong correlation was observed between the amount of pharmaceuticals dispensed in the CAPS and their excretion as an unchanged drug 
and their concentration levels in the surface water (the amount of $\mathrm{CZ}$ that would go to the Belém River would be $19.7 \mathrm{~g}$ - estimating that $10 \%$ is excreted as unchanged drug, and the amount of DZ would be $0.194 \mathrm{~g}$ - calculating that $3 \%$ is excreted as unchanged drug) (Moffat et al., 2004). CAPS provide a regionalized service, implying the delineation of specific geographical areas. These two CAPS studied delimited the region on the sub-basin of the Belém River, where houses not connected to the sewage system properly end up discarding their waste into rivers or streams of this subbasin.

Despite diazepam being the most commonly dispensed medication in the community between 2011-2014, carbamazepine was found at much higher concentrations in both the mouth and headspring of the river than diazepam (a maximum concentration of $0.763 \mu \mathrm{g} \mathrm{L} \mathrm{L}^{-1}$ determined in the mouth of the river during dry weather conditions). This can be explained by the fact that carbamazepine is excreted by the human body in approximately 10\% unchanged form, while diazepam is excreted approximately $3 \%$ as an unchanged compound. Therefore, $\mathrm{CZ}$ environmental concentrations are much higher. Other similar observations about carbamazepine are reported (Glassmeyer et al., 2009; Subedi and Kannan, 2015). To date, diazepam has not been extensively reported.

Because of the importance of these substances to public health, according to the ecotoxicological point of view (Alonso et al., 2010; Brodin et al., 2014; Petersen et al., 2014; Rosi-Marshall et al., 2015), it is essential to ascertain their occurrence in surface water systems, even though it is not contemplated in Brazilian environmental legislation. Further studies of this are extremely necessary to support the establishment of legal parameters of drug residues in aqueous matrices.

The proposed HPLC-DAD method showed specificity, accuracy and sensitivity, good linearity for both analytes (R> 0.9998) and LOD and LOQ were found to be suitable for environmental analysis with a preconcentration step (micrograms per liter or parts per billion). This paper provided a useful and expressive guidance on HPLC-DAD that is in accordance with validation requirements for pharmaceutical analysis in water samples. To our knowledge, this is the first study reporting the method validation of the psychoactive drugs by SPE-HPLC-DAD for river water, especially in developing countries such as Brazil.

\section{ACKNOWLEDGMENTS}

We gratefully acknowledge the Federal University of Paraná (UFPR) and the financial support of Conselho Nacional de Desenvolvimento Científico e Tecnológico (CNPq), Fundação Araucária and Coordenação de Aperfeiçoamento de Pessoal de Nível Superior (CAPES).

\section{REFERENCES}

AGÊNCIA NACIONAL DE VIGILÂNCIA SANITÁRIA (Brasil). Resolução nº 899 de 29 maio de 2003. Determina a publicação do Guia para Validação de Métodos Analíticos e Bioanalíticos. Diário Oficial [da] União, Brasília, DF, 02 jun. 2003.

ALMEIDA, C. A. A.; BRENNER, C. G.; MINETTO, L.; MALLMANN, C. A.; MARTINS, A. F. Determination of anti-anxiety and anti-epileptic drugs in hospital effluent and a preliminary risk assessment. Chemosphere, v. 93, p.2349-2355, 2013. https://doi.org/10.1016/j.chemosphere.2013.08.032

AlONSO, S. G.; CATAlÁ, M.; MAROTO, R. R.; GIL, J. L. R. A.; MIGUEL, Á. G.; VALCÁRCEL, Y. Pollution by psychoactive pharmaceuticals in the Rivers of Madrid metropolitan area (Spain). Environment International, v. 36, p. 195-201, 2010. http://dx.doi.org/10.1016/j.envint.2009.11.004 
ALYGIZAKIS, A. N.; GAGO-FERRERO, P.; BOROVA, V.; PAVLIDOU, A.; HATZIANESTIS, L. THOMAIDIS, S. N. Occurrence and spatial distribution of 158 pharmaceuticals, drugs of abuse and related metabolites in offshore seawater. Science of $\begin{array}{llllll}\text { Total Environment, } & \text { v. 514, p. }\end{array}$ http://dx.doi.org/10.1016/j.scitotenv.2015.09.145

AMARAL, B.; DE ARAUJO, J. A.; ZAMORA, P. G. P.; NAGATA, N. Simultaneous determination of atrazine and metabolites (dia and dea) in natural water by multivariate electronic spectroscopy. Microchemical Journal, v. 117, p. 262-267, 2014. http://dx.doi.org/10.1016/j.microc.2014.07.008

BÖGER, B.; TONIN, F. S.; ZAMORA, P. G. P; WAGNER, R.; GOMES, E. C. Micropoluentes emergentes de origem farmacêutica em matrizes aquosas do Brasil: uma revisão

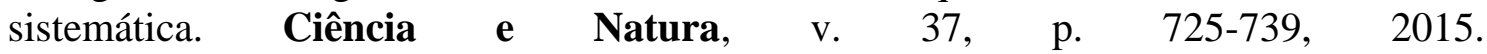
http://dx.doi.org/10.5902/2179460X18174

BRODIN, T.; PIOVANO, S.; FICK, J.; KLAMINDER, J.; HEYNEN, M.; JONSSON, M. Ecological effects of pharmaceuticals in aquatic systems - impacts through behavioural alterations. Philosophical Transactions of Royal Society B Biological Sciences, v. 369, p. 1656, 2014. http://dx.doi.org/10.1098/rstb.2013.0580

CABEZA, Y.; CANDELAA, L.; RONENB, D.; TEIJONA, G. Monitoring the occurrence of emerging contaminants in treated wastewater and groundwater between 2008 and 2010. The Baix Llobregat (Barcelona, Spain). Journal of Hazardous Materials, v. 239, p.3239, 2012. http://dx.doi.org/10.1016/j.jhazmat.2012.07.032

CAMACHO-MUNOZ, D.; MARTIN, J.; SANTOS, L. J.; APARICIO, I.; ALONSO, E. An affordable method for the simultaneous determination of the most studied pharmaceutical compounds as wastewater and surface water pollutants. Journal of Separation Science, v. 32, p. 3064-3073, 2009.

CAMPANHA, M. C.; AWAN, A. T.; DE SOUSA, D. N.; GROSSELI, G. M.; MOZETO, A. A.; FADINI, P.S. A 3-year study on occurrence of emerging contaminants in an urban stream of São Paulo State of Southeast Brazil. Environmental Science and Pollution Research, v. 22, p. 7936-47, 2015.

CLARA, M.; STRENN, B.; KREUZINGER, N. Carbamazepine as a possible anthropogenic marker in the aquatic environment: investigations on the behaviour of Carbamazepine in wastewater treatment and during groundwater infiltration. Water Research, v. 38, p. 947-954, 2004.

CONSELHO REGIONAL DE MEDICINA DO ESTADO DE SÃO PAULO - CREMESP. Jornal do CREMESP, v. 183, n. 11, 2002.

EBERT, I.; HICKMANN, S.; KÜSTER. A. Environmental relevance of pharmaceuticals: The global perspective. Risk Assessment of Pharmaceuticals. Geneva: UBA, 2014. Available in: www.pharmaceuticals-in-the-environment.org. Accessed: 12 Jun. 2015.

FEDERAÇÃO NACIONAL DE FARMACEUTICOS - FENAFAR. O consumo de medicamentos no Brasil. Available in: http://www.fenafar.org.br/fenafar/crf/item/7966o-consumo-de-medicamentos-no-brasil-a-tenue-linha-entre-o-remedio-e-o-veneno-porrilke-novato. Accessed: 23 Sept. 2015. 
FENT, K.; WENSTON, A. A; CAMINADA, D. Ecotoxicology of human pharmaceuticals. $\begin{array}{llllll}\text { Aquatic } & \text { Toxicology, } & \text { v. } & 76, & \text { p. } & 122-59,\end{array}$ http://dx.doi.org/10.1016/j.aquatox.2005.09.009

GLASSMMEYER, S. T.; HINCHEY, E. K.; BOEHME, S. E. et al. Disposal practices for unwanted residential medications in the United States. Environment International, v. 35, n.3, p. 566-72, 2009. http://dx.doi.org/10.1016/j.envint.2008.10.007

GOMEZ, M. J.; AGUERA, A.; MEZCUA, M.; HURTADO, J.; MOCHOLI, F.; FERNANDEZ- ALBA, R. A. Simultaneous analysis of neutral and acidic pharmaceuticals as well as related compounds by gas chromatography-tandem mass spectrometry in wastewater. Talanta, v. 73, p. 314-320, 2007. http://dx.doi.org/10.1016/j.talanta.2007.03.053

GROS, M.; PETROVIC, M.; BARCELÓ, D. Development of a multi-residue analytical methodology based on liquid chromatography-tandem mass spectrometry (LCMS/MS) for screening and trace level determination of pharmaceuticals in surface and $\begin{array}{llllll}\text { wastewaters. } & \text { Talanta, } & \text { v. } & \text { 70, } & \text { p. 678-690, }\end{array}$ http://dx.doi.org/10.1016/j.talanta.2006.05.024

HUF, G.; LOPES, C. S.; ROSENFELD, S. O uso prolongado de benzodiazepínicos em mulheres de um centro de convivência para idosos. Cadernos de Saúde Pública, v. 16, n. 2, p. 351-62, 2000. http://dx.doi.org/10.1590/S0102-311X2000000200006

HUNTSCHA, S.; SINGER, H. P.; MCARDELL, C. S.; FRANK, C. S.; HOLLENDER, J. Multiresidue analysis of 88 polar micropolluants in ground, surface and wastewater using online mixed-bed multilayer solid-phase extraction coupled to HPLC tandem mass spectrometry. Journal of Chromatography A, v. 1268, p. 74-83, 2012. http://dx.doi.org/10.1016/j.chroma.2012.10.032

INSTITUTO NACIONAL DE METEOROLOGIA - INMET. Número de dias com precipitação maior ou igual a 1 mm (dias). 2015. Available in:: http://www.inmet.gov.br/portal/. Accessed: 02 Oct. 2015.

INSTITUTO NACIONAL DE METROLOGIA, NORMALIZAÇÃO E QUALIDADE INDUSTRIAL - INMETRO. DOQ-CGCRE-008. Orientações sobre validação de métodos analíticos, INMETRO. Rio de Janeiro, 2010. Available in: http://www.inmetro.gov.br/Sidoq/Arquivos/Cgcre/DOQ/DOQ-Cgcre-8_04.pdf. Accessed: 25 Mar. 2015.

JORGENSEN, S. E.; HALLING-SORENSEN, B. Drugs in the environment. Chemosphere, v. 40, n.7, p.691-699, 2000. http://dx.doi.org/10.1016/S0045-6535(99)00438-5

LI, W.C. Occurrence, headsprings, and fate of pharmaceuticals in aquatic environment and soil. $\begin{array}{llllll}\text { Environmental Pollution, } & \text { v. 187, }\end{array}$ http://dx.doi.org/10.1016/j.envpol.2014.01.015

MADUREIRA, T. V.; ROCHA. M.; CASS, Q. B.; TIRITAN, M. E. Development and optimization of HPLC-DAD method for the determination of diverse pharmaceuticals in estuarine surface waters. Journal of Chromatography Science, v. 48, n. 3, p. 176-182, 2010. http://dx.doi.org/10.1093/chromsci/48.3.176

MENKEN, M.; MUNSAT, T. L.; TOOLE, J. F. The global burden of disease study: implications for neurology. Archives of Neurology, v. 57, n. 3, p. 418-420, 2000. http://dx.doi.org/10.1001/archneur.57.3.418 
MOFFAT, A. C.; OSSELTON, M. D.; WIDDOP, B.; WATT, S. J. Clarke's Analysis of Drugs and Poisons. London: Pharmaceutical Press, 2004.

MONTAGNER, C. C; JARDIM, F. W. Spatial and seasonal variations of pharmaceuticals and endocrine disruptors in the Atibaia River, São Paulo State (Brazil). Journal of the Brazilian Chemical Society, v. 22, n. 8, p. 1452-1462, 2011.

MORLEY, N. J. Environmental risk and toxicology of human and veterinary waste: pharmaceutical exposure to aquatic host-parasite relationships. Environmental

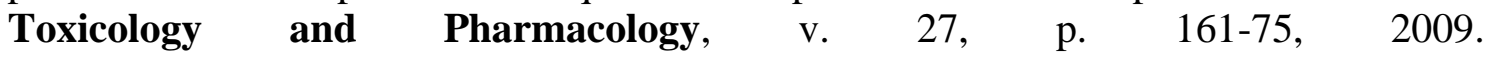
http://dx.doi.org/10.1016/j.etap.2008.11.004

MOTA, D. M. Panorama dos dados do Sistema Nacional de Gerenciamento de Produtos Controlados: um sistema para o monitoramento de medicamentos no Brasil. Boletim de farmacoepidemiologia do SNGPC, v. 2, ano 1, 2011.

PAL, R.; MEGHARAJ, M.; KIRKBRIDE, K. P.; NAIDU, R. Illicit drugs and the environment-a review. Science of Total Environment, v. 1, p. 463-464, 2013. http://dx.doi.org/10.1016/j.scitotenv.2012.05.086

PATROLECCO, L.; ADEMOLLO, N.; GRENNI, P.; TOLOMEI, A.; CARACCIOLO, A.B.; CAPRI, S. Simultaneous determination of human pharmaceuticals in water samples by solid phase extraction and HPLC with UV-fluorescence detection. Microchemical Journal, v. 107, p.165-171, 2013.

PETERSEN, K.; HEIAAS, H. H.; TOLLEFSEN, K. E. Combined effects of pharmaceuticals, personal care products, biocides and organic contaminants on the growth of Skeletonema $\begin{array}{llllll}\text { pseudocostatum. Aquatic Toxicology, v. 150, p. 45-54, } 2014 . & \end{array}$ http://dx.doi.org/10.1016/j.aquatox.2014.02.013

RANG, H. P. et al. Farmacologia. 5. ed. Rio de Janeiro: Elsevier, 2003.

ROSI-MARSHALL, E. J.; SNOW, D.; BARTELT-HUNT, S. L.; PASPALOF, A.; TANK, J. L. A review of ecological effects and environmental fate of illicit drugs in aquatic ecosystems. Journal of Hazardous Materials, v. 282, p. 18-25, 2015. http://dx.doi.org/10.1016/j.jhazmat.2014.06.062

SEBASTIÃO, E. C. O.; PELÁ, I. R. Consumo de medicamentos psicotrópicos: análisis de recetas médicas ambulatorias como base para estudios de problemas relacionados con medicamentos. Seguimiento Farmacoterapico, v. 2, n. 4, p. 250-266, 2004.

STUART, M.; LAPOWORTH, D.; CRANE, E.; HART, A. Review of risk from potential emerging contaminants in UK groundwater. Science of Total Environment, v. 416, p. 1-21, 2012. http://dx.doi.org/10.1016/j.scitotenv.2011.11.072

SUBEDI, B.; KANNAN, K. Ocurrence and fate of select psychoactive pharmaceuticals and antihypertensives in two waste treatment plants in New York State, USA. Science of $\begin{array}{llllll}\text { Total Environment, } & \text { v. } & 514, & \text { p. } & 273-280, & \end{array}$ http://dx.doi.org/10.1016/j.scitotenv.2015.01.098 